\title{
Correction to: Non-isothermal Phase-Field Modeling of Heat-Melt-Microstructure-Coupled Processes During Powder Bed Fusion
}

\author{
YANGYIWEI YANG ®D, ${ }^{1,4}$ PATRICK KÜHN $®{ }^{1}$ MIN YI $\odot{ }^{2}$, \\ HERBET EGGER ${ }^{3}$ and BAI-XIANG XU (i) ${ }^{1,5}$
}

1.--Mechanics of Functional Materials Division, Institute of Materials Science, Technische Universitcät Darmstadt, 64287 Darmstadt, Germany. 2.-State Key Laboratory of Mechanics and Control of Mechanical Structures \& Key Laboratory for Intelligent Nano Materials and Devices of Ministry of Education \& College of Aerospace Engineering, Nanjing University of Aeronautics and Astronautics (NUAA), Nanjing 210016, China. 3.-Department of Mathematics, Technische Universität Darmstadt, 64293 Darmstadt, Germany. 4.-e-mail: yangyiwei.yang@mfm.tudarmstadt.de. 5.—e-mail: xu@mfm.tu-darmstadt.de

\section{CORRECTION TO: JOM, VOL. 72, NO. 4, 2020, HTTPS://DOI.ORG/10.1007/ S11837-019-03982-Y}

The article "Non-isothermal Phase-Field Modeling of Heat-Melt-Microstructure-Coupled Processes During Powder Bed Fusion" written by Yang et al. was originally published electronically on the publisher's internet portal on January 17, 2020 without open access. With the author(s)' decision to opt for Open Choice the copyright of the article changed on October 10, 2020 to (C) The Author(s) 2020 and the article is forthwith distributed under a Creative Commons Attribution 4.0 International License, which permits use, sharing, adaptation, distribution and reproduction in any medium or format, as long as you give appropriate credit to the original author(s) and the source, provide a link to the Creative Commons licence, and indicate if changes were made.

The images or other third party material in this article are included in the article's Creative Commons licence, unless indicated otherwise in a credit line to the material. If material is not included in the article's Creative Commons licence and your intended use is not permitted by statutory regulation or exceeds the permitted use, you will need to obtain permission directly from the copyright holder.

To view a copy of this licence, visit http://creativec ommons.org/licenses/by/4.0/.

Publisher's Note Springer Nature remains neutral with regard to jurisdictional claims in published maps and institutional affiliations. 